\title{
Pengaturan Perjanjian Pengikatan Jual Beli Atas Rumah Tempat Tinggal Oleh Warga Negara Asing Dengan Berlakunya Peraturan Menteri Agraria Dan Tata Ruang Nomor 29 Tahun 2016
}

\author{
Made Utami Jayanti ${ }^{1}$ \\ ${ }^{1}$ Magister Kenotariatan Fakultas Hukum Universitas Udayana, E-mail: \\ amyjayanti@rocketmail.com/WA : 08985693390
}

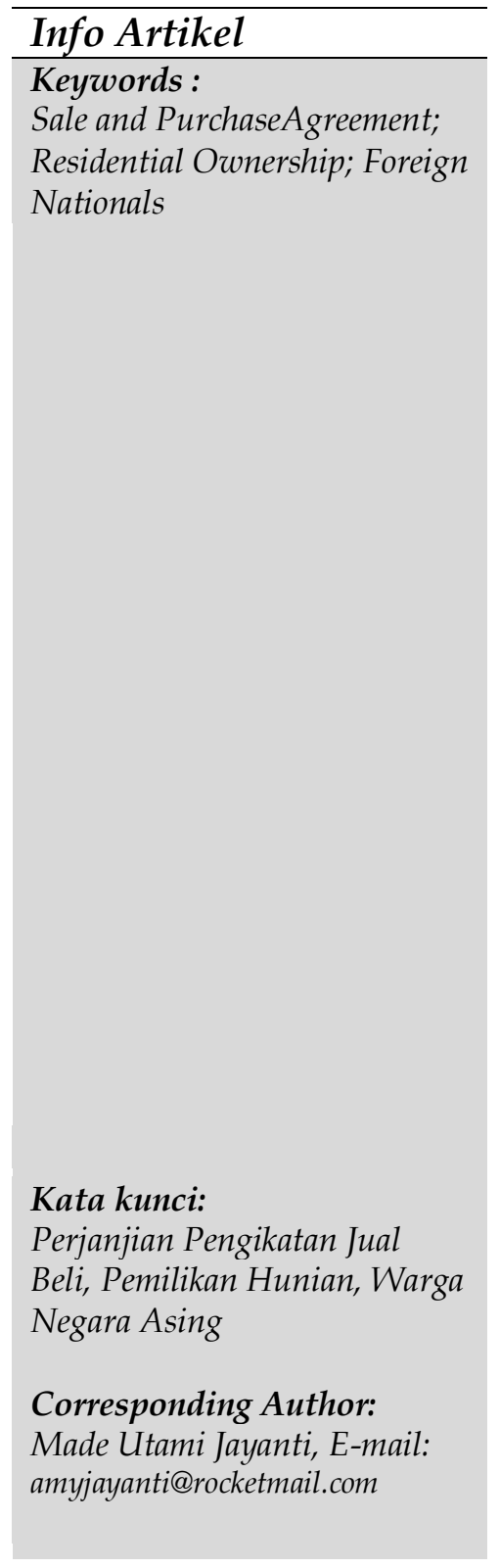

\begin{abstract}
The enactment of Minister of Agrarian and Spatial Planning Number 29 of 2016 concerning Procedures for Granting, Releasing, or Transferring the Right to Ownership of Residential Houses by Foreigners Domiciled in Indonesia has not sufficiently accommodated the interests of Foreign Citizen while in Indonesia. This is evidenced by the lack of sufficient rules to protect the interests of foreign national while implementing a sale and purchase agreement on ownership of a residence during their domicile in Indonesia. This research is a normative legal research. Normative legal research consists of statute approach and legal concepts. The legal material collection technique was by using snowball techniques. The results of the study show that the regulation of residential property that can be owned by foreign nationals while domiciled in Indonesia is not sufficient to provide legal protection for foreign nationals in the event of losses, which require foreigners to pay for the shortage of the nominal purchase of a residential house due to the transition of legislation. The importance of establishing new legislation regarding the ownership of housing by foreigners during their domicile in Indonesia as an effort to realize legal protection for foreign nationals who have contributed to the development of the national economy. The Indonesian government should immediately make or amend the laws and regulation concerning the ownership of houses by foreigners. This must be done so as not to reduce the trust of foreign nationals to invest in Indonesia, which will certainly have an impact on the national economy.

\begin{tabular}{l}
\hline Abstrak \\
\hline Berlakunya Permen Agraria dan Tata Ruang Nomor 29 \\
Tahun 2016 tentang Tata Cata Pemberian, Pelepasan, atau \\
Pengalihan Hak atas Pemilikan Rumah Tempat Tinggal \\
atau Hunian oleh Orang Asing yang Berkedudukan di \\
Indonesia belum cukup mengakomodir kepentingan- \\
kepentingan Warga Negara Asing selama berada di \\
Indonesia. Hal ini dibuktikan dengan belum terdapat \\
aturan yang cukup untuk melindungi kepentingan Warga \\
Negara Asing selama melaksanakan perjanjian jual beli
\end{tabular}
\end{abstract}




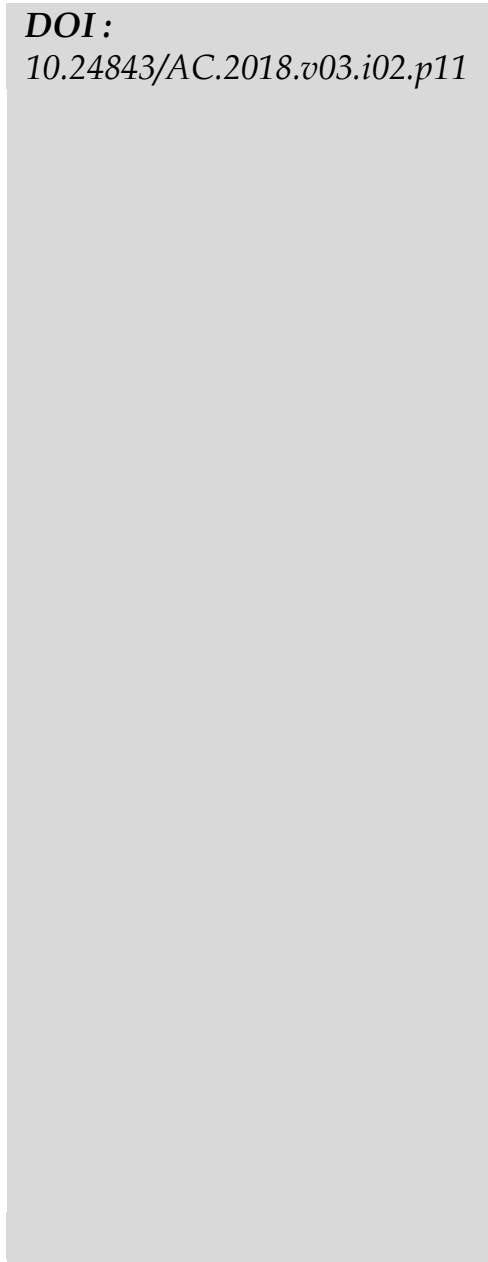

\begin{abstract}
atas pemilikan rumah tempat tinggal selama berkedudukan di Indonesia. Penelitian ini adalah penelitian hukum normatif. Penelitian hukum normatif terdiri dari pendekatan perundang-undangan dan konsep hukum. Teknik pengumpulan bahan hukum yaitu menggunakan teknik bola salju. Hasil penelitian menunjukan bahwa, Pengaturan tentang pemilikan rumah tempat tinggal yang dapat dimiliki Warga Negara Asing selama berkedudukan di Indonesia belum cukup memberikan perlindungan hukum bagi Warga Negara Asing dalam hal kerugian yang diderita, yang mengharuskan Warga Negara Asing untuk membayar kekurangan dari nominal pembelian rumah tempat tinggal akibat adanya transisi peraturan perundang-undangan. Pentingnya pembentukan peraturan perundang-undangan baru mengenai pemilikan rumah tempat tinggal oleh Warga Negara Asing selama berkedudukan di Indonesia sebagai upaya untuk mewujudkan perlindungan hukum bagi Warga Negara Asing yang telah berkontribusi dalam pembangunan perekonomian nasional. Pemerintah Indonesia hendaknya segera membuat atau merubah peraturan perundang-undangan mengenai pemilikan rumah tempat tinggal oleh Warga Negara Asing. Hal ini dilakukan agar tidak mengurangi rasa percaya Warga Negara Asing dalam melakukan kegiatannya untuk berinvestasi di Indonesia yang tentunya akan berdampak pada perekonomian nasional.
\end{abstract}

\title{
1. Pendahuluan
}

Orang asing yang datang ke Indonesia mempunyai tujuan yang beranekaragam dan berkunjung dalam jangka waktu yang lama ataupun berkunjung dalam jangka waktu yang singkat. Berbagai macam tujuan orang asing itu pada saat melakukan kegiatannya di Indonesia, mendorong keinginan orang asing untuk mempunyai tempat tinggal di Indonesia. Orang asing yang memilih untuk bertempat tinggal di Indonesia dapat menimbulkan dampak positif bagi perkembangan perekonomian di Indonesia salah satunya dengan melakukan investasi di Indonesia.

Pemilikan atas tanah dan/atau kepemilikan atas bangunan pembangunan perumahan serta pemukiman baik itu untuk Warga Negara Indonesia (WNI) ataupun diperuntukkan untuk orang asing (Warga Negara Asing/WNA) sudah diatur dalam Peraturan Perundang-Undangan yaitu pada Peraturan Pemerintah Nomor 103 Tahun 2015 tentang Pemilikan Rumah Tempat Tinggal atau Hunian oleh Orang Asing yang Berkedudukan di Indonesia (selanjutnya disebut dengan PP Nomor 103 Tahun 2015).

Sebagai bentuk dukungan terhadap kemajuan perekonomian serta pembangunan di Indonesia, pada bulan Maret 2016 Pemerintah mengeluarkan peraturan pelaksana dari PP Nomor 103 Tahun 2015, yaitu Peraturan menteri Agraria dan Tata Ruang/Kepala Badan Pertanahan Nasional Nomor 13 Tahun 2016 tentang Tata Cara Pemberian, 
Pelepasan atau Pengalihan Hak atas Pemilikan Rumah Tempat Tinggal atau Hunian oleh Orang Asing yang Berkedudukan di Indonesia (selanjutnya disebut dengan Permen Agraria dan Tata Ruang Nomor 13 Tahun 2016. Permen Nomor 13 Tahun 2016, ini mengatur secara spesifik syarat-syarat yang harus dipenuhi oleh WNA dalam memiliki hunian di Indonesia, salah satunya mengenai minimal pembelian hunian oleh WNA, sebagaimana diatur dalam lampiran Permen Agraria dan Tata Ruang Nomor 13 Tahun 2016.

Berlakunya Permen Agraria dan Tata Ruang Nomor 13 Tahun 2016 dianggap kurang optimal mengatur pemilikan hunian oleh orang asing di Indonesia. Pada Bulan September 2016, pemerintah mengeluarkan Permen Agraria dan Tata 29 Tahun 2016, sebagai peraturan yang menggantikan Permen Nomor 13 Tahun 2016 sebelumnya dicabut dan dinyatakan tidak berlaku. Mengenai nominal minimal pembelian hunian oleh WNA pada Permen Agraria dan Tata Ruang Nomor 29 Tahun 2016, dibandingkan dengan Peraturan Menteri Agraria dan Tata Ruang sebelumnya terdapat peningkatan harga minimal pembelian hunian orang asing pada tiap daerah.

Sebelum berlakunya Peraturan Menteri Agraria dan Tata Ruang Nomor 29 Tahun 2016, tidak menutup kemungkinan PPJB atas hunian yang dibeli oleh WNA masih memuat minimal pembelian sebagaimana termuat pada Permen Agraria dan Tata Ruang Nomor 13 Tahun 2016 yang dinyatakan sudah dicabut dan tidak berlaku.

Ketentuan Perjanjian Pengikatan Jual Beli (selanjutnya disebut dengan PPJB) yang memuat kesepakatan para pihak tersebut yang masih dalam proses pembuatan Akta Jual Beli (selanjutnya disebut dengan AJB) dan syarat-syaratnya masih dalam proses pengurusan, setelah berlakunya Permen Agraria dan Tata Ruang baru yaitu Permen Agraria dan Tata Ruang Nomor 29 Tahun 2016, mewajibkan orang asing untuk membuat perjanjian dengan memuat minimal pembelian hunian yang memiliki peningkatan nominal pembelian hunian dibandingkan dengan Peraturan Menteri Agraria dan Tata Ruang sebelumnya.

Hal tersebut jelas merugikan WNA yang telah membayar lunas hunian di Indonesia sesuai dengan minimal pembelian hunian pada Permen Agraria dan Tata Ruang sebelumnya. Tidak adanya norma yang menentukan apabila orang asing yang telah membayar lunas hunian berdasarkan Permen ATR Nomor 13 Tahun 2016 tersebut tetapi dalam hal ini pemerintah mengeluarkan Permen ATR Nomor 29 Tahun 2016 yang mempunyai nilai minimal pembelian hunian yang berbeda dengan peraturan Menteri ATR yang sebelumnya maka dapat menyebabkan kebingungan dalam hal pelaksanaannya di kemudian hari.

Tujuan dari penulisan ini, yaitu tujuan umum dan tujuan khusus. Tujuan umum dari penulisan ini adalah untuk pengembangan ilmu hukum, lebih khususnya pada bidang hukum Agraria kaitannya dengan Pelaksanaan PPJB atas Pemilikan Hunian Warga Negara Asing didasarkan atas Peraturan Menteri Agraria dan Tata Ruang Nomor 29 Tahun 2016. Tujuan khusus penelitian ini yakni agar dapat mengetahui pengaturan yang mengatur tentang PPJB antara WNA dengan WNI dalam pemilikan hunian oleh orang asing serta untuk mengkaji dan menganalisis secara normatif akibat hukum atas adanya kekosongan norma pada Permen Agraria dan Tata Ruang Nomor 29 Tahun 2016 teruntuk WNA yang dirugikan dalam pelaksanaan PPJB dengan WNI. 
Manfaat penulisan jurnal ini yaitu manfaat teoritis dan manfaat praktis. Hasil penelitian ini, secara teoritis dapat memberikan kontribusi terhadap perkembangan ilmu hukum yang berkaitan dengan Pelaksanaan Perjanjian Pengikatan Jual Beli atas Pemilikan Hunian Warga Negara Asing didasarkan atas Peraturan Menteri Agraria dan Tata Ruang Nomor 29 Tahun 2016. Hasil penelitian ini, secara praktis mampu memberikan kontribusi salah satunya untuk memberikan pemikiran bagi masyarakat secara umum tentang kepemilikan atas hunian oleh orang asing. Bagi penulis sendiri, agar dapat lebih menambah pengetahuan serta wawasan dalam bidang hukum perjanjian, serta agraria, secara spesifik terkait Pengaturan Perjanjian Pengikatan Jual Beli atas Pemilikan Hunian Warga Negara Asing didasarkan atas Peraturan Menteri Agraria dan Tata Ruang Nomor 29 Tahun 2016.

\section{Metode Penelitian}

Penelitian ini menggunakan jenis penelitian hukum normatif. Penelitian hukum normatif disebut juga sebagai penelitian doktrinal, yaitu penelitian yang objek kajiannya adalah dokumen peraturan perundang-undangan dan bahan pustaka. ${ }^{1}$ Tulisan ini didasarkan atas adanya kekosongan norma pada Permen Agraria dan Tata Ruang Nomor 29 Tahun 2016 yang belum mengatur tentang perlindungan hukum terhadap WNA yang dirugikan terkait dengan diberlakukannya Peraturan Menteri Agraria dan Tata Ruang Nomor 29 Tahun 2016. Jenis pendekatan yang digunakan adalah pendekatan konseptual dan perundang-undangan. Berkaitan dengan masalah yang dikaji, pendekatan konsep digunakan untuk menemukan konsep yang berkaitan dengan permasalahan yang dikaji. Pendekatan perundang-undangan dilakukan dengan mengkaji peraturan yang berkaitan dengan peraturan Permen Agraria dan Tata Ruang Nomor 29 Tahun 2016. Sumber bahan hukum yang digunakan dalam penelitian ini adalah sumber bahan hukum primer, bahan hukum sekunder dan bahan hukum tersier. Undang-Undang Dasar Negara Republik Indonesia Tahun 1945, Kitab Undang-Undang Hukum Perdata, Undang-Undang Nomor 5 Tahun 1960 Tentang Peraturan Dasar Pokok-Pokok Agraria, PP Nomor 103 Tahun 2015, dan Permen Agraria dan Tata Ruang Nomor 29 Tahun 2016 sebagai bagian dari bahan hukum primer. Jurnal nasional, tesis, serta disertasi sebagai bagian dari sumber bahan hukum sekunder. Sumber bahan hukum yang menunjang bahan hukum primer dan bahan hukum sekunder yaitu bahan hukum tersier, yang terdiri dari penelitian yang dicari melalui situs internet kredibel. Teknik pengumpulan bahan hukum yang digunakan dalam penelitian ini menggunakan teknik bola salju (snow ball system). Teknik metode bola salju menjadi salah satu cara untuk menemukan bahan hukum sebanyak mungkin melalui sumber dari berbagai literatur hukum. ${ }^{2}$ Teknik analisis bahan hukum yang digunakan pada penulisan ini meliputi teknik deskripsi, evaluasi, dan argumentasi. Teknik deskripsi yaitu dengan menjabarkan suatu peristiwa hukum yang terjadi.

\footnotetext{
${ }^{1}$ Marzuki, P. M. (2011). Penelitian Hukum. Jakarta: Kencana Prenida Media. h. 34.

2 Jaya, I. G. P., Utama, I. M. A., \& Westra, I. K. (2018). KEKUATAN HUKUM SERTIFIKAT HAK TANGGUNGAN DALAM HAL MUSNAHNYA OBYEK HAK TANGGUNGAN KARENA BENCANA ALAM. Acta Comitas, 277-285.
} 
Teknik evaluatif dilakukan melalui penafsiran teologikal yaitu dengan mencari maksud dan tujuan dibuatnya peraturan perundang-undangan. ${ }^{3}$

\section{Hasil Dan Pembahasan}

\subsection{Pengaturan mengenai PPJB antara WNA dengan WNI dalam hal Pemilikan Rumah Tempat Tinggal oleh Orang Asing}

Warga Negara Indonesia maupun Warga Negara Asing tidak memandang kebudayaan maupun agama, dari dilahirkan hingga meninggal dunia merupakan subjek hukum, sebagai pemegang hak dan kewajiban. Manusia mempunyai hak-hak serta kewajiban sebagai subjek hukum dalam melaksanakan suatu perbuatan hukum. Salah satu bentuk tindakan hukum dalam hal ini yaitu dengan membuat persetujuanpersetujuan. Berdasarkan ketentuan Pasal 1313 KUHPerdata, suatu persetujuan adalah suatu perbuatan dimana satu orang atau lebih mengikatkan diri terhadap satu orang atau lebih. Rumusan pasal tersebut, menegaskan bahwa dari suatu persetujuan lahirlah kewajiban atau prestasi dari satu orang atau lebih kepada satu orang atau lebih lainnya, yang berhak atas prestasi tersebut.4

Kaitannya dengan pemilikan rumah tempat tinggal yaitu agar proses pemilikan rumah tempat tinggal berjalan dengan baik wajib ada suatu perbuatan hukum yang mendasari proses pemilikan rumah, dalam hal ini yaitu perbuatan hukum jual beli. Jual beli ditentukan dalam Pasal 1457 KUHPerdata, yang menentukan bahwa jual beli adalah suatu persetujuan dengan mana pihak yang satu mengikatkan dirinya untuk menyerahkan suatu barang, dan pihak yang lain untuk membayar harga yang dijanjikan. Pihak penjual menyerahkan atau memindahkan hak miliknya atas barang yang ditawarkan, dan pihak pembeli membayar harga yang telah disepakati.

PPJB adalah perjanjian awal para pihak sebelum dibuatnya AJB dihadapan PPAT. Pada prakteknya dalam jual beli, pihak pembeli memerlukan adanya sertifikat sebagai bukti kepemilikan atas hak atas tanah yang dibelinya, namun hak atas tanah yang dimilikinya belum mempunyai sertifikat. Hal ini tentunya dapat menghambat pembuatan AJB, dikarenakan PPAT akan menolak untuk membuatkan AJB oleh karena adanya persyaratan yang belum dapat dipenuhi. Salah satu cara agar proses jual beli dapat berjalan dengan baik, maka para pihak sepakat bahwa jual beli akan diurus setelah sertifikat selesai diurus, atau setelah harga dibayar lunas. Agar kesepakatan tersebut dapat terlaksana dengan baik, biasanya para pihak akan melakukan perbuatan hukum jual beli yang kemudian menuangkan kesepakatan awal dalam bentuk perjanjian yang kemudian disebut dengan PPJB.

Fungsi akta Pejabat Pembuat Akta Tanah (PPAT) dibuat sebagai bukti bahwa benar telah dilakukan perbuatan hukum yang bersangkutan. Oleh karena perbuatan tersebut sifatnya tunai, hal ini membuktikan bahwa hak atas tanah yang bersangkutan telah berpindah kepada penerima hak. Setelah didaftarkan hak atas tanah tersebut, kemudian sertifikat tersebut dapat digunakan sebagai alat bukti yang mempunyai

\footnotetext{
${ }^{3}$ Diantha, I. M. P. (2017). Metodologi Penelitian Hukum Normatif. Denpasar: Prenada Media Group. h. $152-154$

${ }^{4}$ Muljadi, K., \& Widjaja G. (2010). Perikatan yang Lahir dari Perjanjian. Jakarta: Rajawali Pers. h. 92.
} 
kekuatan hukum, yang berlaku juga kepada pihak ketiga, oleh karena tata usaha pendaftaran tanah Kantor Pertanahan mempunyai sifat terbuka untuk umum. ${ }^{5}$ Dampak hukum terhadap lahir, berubahnya, maupun lenyapnya suatu perbuatan hukum tertentu adalah sejak haknya dimohonkan baik secara langsung menggunakan akta pelepasan hak dan akta peralihan hak, maka saat itu juga pihak yang mendapatkan hak tersebut atau Warga Negara Asing menjadi pemilik sah. ${ }^{6}$

Masyarakat hukum adat yang melakukan transaksi jual beli harus dilaksanakan secara terang dan tunai. Terang berarti, perbuatan hukum jual beli tersebut benar-benar dilaksanakan dihadapan Kepala adat atau Kepala Desa, sedangkan tunai berarti adanya dua perbuatan yang dilakukan secara bersamaan, yaitu pemindahan hak atas tanah yang menjadi objek jual beli dari penjual kepada pembeli dan pembayaran harga dari pembeli kepada penjual serentak dan secara bersamaan. ${ }^{7}$

Pada PPJB, tidak terlepas dari adanya keharusan atas terpenuhinya syarat sahnya suatu perjanjian sebagaimana diatur dalam ketentuan KUHPerdata yaitu, pertama harus adanya persetujuan terhadap pihak- pihak yang memiliki kewajiban satu sama lain. Kedua, harus cakap dalam membuat suatu persetujuan, kemudian yang ketiga, adanya objek yang dapat ditentukan, dan terakhir terdapat adanya kausa yang tidak dilarang oleh Undang-Undang.

Untuk membuat perjanjian yang sah mengikat kedua belah pihak layaknya undangundang bagi para pihak tersebut haruslah memenuhi seluruh persyaratan sahnya perjanjian. ${ }^{8}$ Perjanjian yang sifatnya mengikat bagi kedua belah pihak diatur juga dalam ketentuan KUHPerdata, yang menentukan segala kesepakatan sebagai UndangUndang bagi para pihak yang merancangnya. Kesepakatan tersebut tak bisa dicabut lagi disamping atas persetujuan para pihak, maupun oleh sebab-sebab yang diatur pada Undang-Undang. Kesepakatan tersebut haruslah dilaksanakan dengan maksud baik. Suatu Persetujuan yang dirancang oleh para pihak tak bisa batal dengan satu pihak tanpa ada persetujuan pihak lainnya. Hal ini dilakukan agar kepentingan dari para pihak dapat terlindungi, sebab pada saat persetujuan atas dasar persetujuan para pihak maka dibatalkannnya pun harus dengan persetujuan para pihak. Suatu persetujuan dapat dibatalkan secara sepihak jika terdapat pertimbangan yang layak oleh peraturan perundang-undangan yang berlaku.

Setiap perjanjian jual beli yang berkaitan dengan tanah, wajib tunduk pada segala aturan yang berkaitan dengan dengan hak atas tanah. Peraturan tentang hak atas tanah, diataranya adalah Undang-Undang Nomor 5 Tahun 1960 Tentang Peraturan Dasar Pokok Agraria (Selanjutnya disebut dengan UUPA), Peraturan Pemerintah Nomor 40 Tahun 1996 Tentang Hak Guna Usaha, Hak Guna Bangunan dan Hak Pakai Atas Tanah (Selanjutnya disebut dengan PP Nomor 40 Tahun 1996), Peraturan menteri Agraria dan Tata Ruang Nomor 3 Tahun 1997 Tentang Ketentuan Pelaksanaan

\footnotetext{
${ }^{5}$ Handayani, E. (2009). Penghindaran Pajak Melalui Perjanjian Pengikatan Jual Beli Dengan Kuasa Jual yang Dibuat di Hadapan Notaris di Jakarta Utara. NOTARIUS, 1(1), 37-52, h.4.

${ }^{6}$ ORANG, P. R. T. T. O. (2017). JURNAL PRASADA. Jurnal Prasada, 4(2), 24-36. h. 32.

7 Rosandi, P., \& Henni, B. (2016). Akibat Hukum Jual Beli Hak Atas Tanah Yang Belum Didaftarkan. Jurnal IUS: Kajian Hukum dan Keadilan, 4(3), h. 429.

8 Karunia, T. Syarat Sahnya Perjanjian. dalam http://www. jurnalhukum. com/syarat-syarat-sahnyaperjanjian/, akses, 3. h. 1.
} 
Peraturan Pemerintah Nomor 24 Tahun 1997 Tentang Pendaftaran Tanah, (Selanjutnya disebut dengan Permen Nomor 3 Tahun 1997), Peraturan Pemerintah Nomor 103 Tahun 2015 Tentang Pemilikan Rumah Tempat Tinggal Atau Hunian Oleh Orang Asing Yang Berkedudukan di Indonesia (selanjutnya disebut dengan PP Nomor 103 Tahun 2015) dan Permen Agraria dan Tata Ruang Nomor 29 Tahun 2016.

Kaitannya dengan pemilikan rumah tempat tinggal Warga Negara Asing, berdasarkan ketentuan Pasal 2 PP Nomor 103 Tahun 2015 mengatur, Warga Negara Asing dapat memiliki rumah tempat tinggal atau hunian dengan Hak Pakai. Orang asing yang memiliki rumah tempat tinggal sebagaimana dimaksud dalam pasal tersebut merupakan orang asing pemegang izin tinggal di Indonesia. Izin tinggal diberikan kepada Warga Negara Asing sesuai dengan Visa yang dimilikinya. ${ }^{9}$ Berdasarkan Undang-Undang Nomor 6 Tahun 2011 tentang Keimigrasian (selanjutnya disebut dengan UU Keimigrasian). Pengertian Visa berdasarkan UU Keimigrasian merupakan suatu pemberitahuan tertulis yang dibuat oleh pejabat yang berwenang diperwakilan republik Indonesia atau ditempat lain yang ditentukan pemerintah Republik Indonesia yang memuat persetujuan untuk Warga Negara Asing dalam melaksanakan perjalannya ke Indonesia serta menjadi alas atas pemberian izin tinggal.

Persyaratan utama untuk pemberian hak pakai yaitu orang asing yang tinggal di Indonesia secara menetap umumnya yang memiliki bisnis atau pekerjaan di Indonesia dan tentunya membutuhkan tempat tinggal. Kepemilikan rumah tempat tinggal bagi WNA yang didapatkan melalui jual beli maka WNA wajib untuk mendaftarkan hak pakai yang dimilikinya ke kentor pertanahan setempat dengan memenuhi persyaratan yang berlaku.

Sebagai pelaksanaan PP Nomor 103 Tahun 2015, dikeluarkanlah Permen Agraria dan Tata Ruang Nomor 13 Tahun 2016, yang mengatur ketentuan minimal pembelian hunian oleh orang asing, yang di dalam lampiran Permen ini diatur mengenai minimal pembelian hunian orang asing, yang berbeda-beda pada tiap daerah.

Pada bulan September 2016, Permen Agraria dan Tata Ruang Nomor 13 Tahun 2016 tersebut dicabut dan diganti dengan Permen Agraria dan Tata Ruang Nomor 29 Tahun 2016. Pertimbangan dicabutnya Permen Agraria dan Tata Ruang Nomor 13 Tahun 2016, karena dirasakan kurang optimal sehingga perlu diganti hal ini sesuai dengan dasar menimbang huruf $b$. Adapun tujuan pergantian ini adalah pertama untuk memberikan kepastian hukum atas pemilikan rumah tempat tinggal atau hunian oleh orang asing; kedua mencegah peralihan hak yang tidak sesuai dengan ketentuan peraturan perundang-undangan atau diluar sistem hukum administrasi pertanahan di Indonesia oleh Warga Negara Asing dengan Warga Negara Indonesia.

Atas dasar Permen Agraria dan Tata Ruang Nomor 29 Tahun 2016, Warga Negara Asing selama berkedudukan di Indonesia, dapat memiliki rumah tempat tinggal yang terdiri atas rumah tunggal dan satuan rumah susun. Rumah tunggal yang dapat dimiliki oleh Warga Negara Asing yaitu rumah tinggal di atas hak pakai dan hak pakai

\footnotetext{
${ }^{9}$ Amalia, R., \& Darmawan, N. K. (2013). Perkawinan Campuran dalam Kaitannya dengan Undang-undang no. 6 Tahun 2011 Tentang Keimigrasian. Jurnal Fakultas Hukum Universitas Udayana. h. 4.
} 
atas hak milik yang dikuasai berdasarkan perjanjian pemberian hak pakai di atas tanah hak milik dengan akta Pejabat pembuat Akta Tanah serta hak pakai yang berasal dari Perubahan Hak Milik atau Hak Guna Bangunan.

Khusus pada rumah tempat tinggal yang dapat dimiliki oleh orang asing, dapat memiliki rumah tempat tinggal pada 1 bidang tanah per orang atau per keluarga dan luas dari rumah tempat tinggal yang dapat dimiliki oleh orang asing tidak memuat lebih dari 2000 meter persegi. Apabila dalam keadaan tertentu yang memiliki dampak positif luar biasa terhadap perekonomian Indonesia maka Warga Negara Asing dapat memiliki rumah tempat tinggal dengan luas lebih dari 2000 meter persegi melalui izin Menteri. Syarat-syarat pemilikan rumah tempat tinggal di atas tersebut tidak berlaku bagi pemilikan rumah tempat tinggal oleh perwakilan negara asing atau perwakilan badan internasional.

Pada Permen Agraria dan Tata Ruang Nomor 29 Tahun 2016 terdapat beberapa perubahan, salah satunya yaitu mengenai ketentuan luas rumah tempat tinggal yang dapat dimiliki oleh Warga Negara Asing serta mengenai minimal pembelian rumah tempat tinggal. Khusus mengenai minimal pembelian rumah tempat tinggal oleh Warga Negara Asing terdapat peningkatan nominal pembelian pada tiap daerah. Terhadap perubahan minimal pembelian rumah tempat tinggal oleh Warga Negara Asing ini tentu akan menyulitkan Warga Negara Asing dalam praktiknya yang masih mengikuti Permen Agraria dan Tata Ruang lama yaitu Permen Agraria dan Tata Ruang Nomor 13 Tahun 2016.

Sebagai perjanjian pendahuluan sebelum dibuatkannya AJB, PPJB harus menyesuaikan isi dari perjanjian tersebut dengan Peraturan Perundang-undangan yang berkaitan dengan hak atas tanah maupun terkait kepemilikan rumah tempat tinggal atau hunian yang dapat dimiliki oleh orang asing. Orang asing dapat memiliki rumah tempat tinggal atau hunian dengan menggunakan hak pakai. Warga Negara Asing yang membuat PPJB dengan Warga Negara Indonesia akan sulit untuk diterima pada saat akan mendaftarkan aktanya ke Badan Pertanahan Nasional. Atas dasar minimal pembelian rumah tempat tinggal tidak sesuai dengan Peraturan Menteri Agraria dan Tata Ruang Nomor 29 Tahun 2016. Pada rentan waktu yang cukup singkat, menyebabkan Warga Negara Asing dan Warga Negara Indonesia belum dapat segera mendaftarkan akta kepada Badan Pertanahan Nasional oleh karena masih dalam proses pemecahan. Tidak menutup kemungkinan dalam hal dibuatnya PPJB, orang asing tersebut sudah melunasi rumah tempat tinggal atau hunian yang dibelinya, namun belum dapat diserahkannya sertifikat oleh pemilik hak atas tanah karena masih dalam proses pemecahan. Dengan belum lengkapnya persyaratan tersebut, maka belum dapat dibuatkannya Akta Jual Beli (AJB) dihadapan PPAT.

Selain itu, jual beli telah dibayar secara lunas dan semua pajak yang berkaitan dengan dengan jual beli seperti pajak penjual (SSP) dan pajak pembeli yaitu Bea Perolehan Hak atas Tanah dan Bangunan (BPHTB) juga telah dilunasi oleh pihak yang akan melakukan jual beli. Setelah semua hal tersebut dilengkapi atau terpenuhi, barulah para pihak yang akan melakukan jual beli rumah tempat tinggal atau hunian dan pembuatan akta jual beli dihadapan PPAT serta selanjutnya melakukan pendaftaran kepada Badan Pertanahan untuk pemindahan haknya. Jika persyaratan-persyaratan tersebut belum terpenuhi maka pembuatan dan penandatanganan akta jual beli atas 
pemilikan rumah tempat tinggal atau hunian oleh orang asing belum bisa dilakukan dihadapan PPAT, dan PPAT tersebut juga akan menolak untuk dibuatkannya akta jual beli sebagai akibat hukum tepenuhinya semua syarat tentang pembuatan AJB.

PPJB bangunan berikut tanah dalam prakteknya sering dibuat dalam bentuk akta otentik yang dibuat dihadapan Notaris, sehingga Akta PPJB merupakan akta otentik yang memiliki kekuatan pembuktian yang sempurna. Hal ini dimaksudkan untuk memberikan perlindungan dan kepastian hukum bagi para pihak yang membuatnya. Jual beli atas bangunan berikut tanah yang dilakukan WNA dengan akta notariil pada hakekatnya memiliki kekuatan hukum terutama dalam hal pembuktian, artinya jika ada pihak yang mengingkari terjadinya jual beli maka akta jual beli notariil bisa dijadikan alat bukti telah terjadinya kesepakatan jual beli. Pembuktian tersebut harus dengan menunjukkan akta asli, sebab kekuatan pembuktian suatu bukti tulisan adalah pada akta aslinya. Kedudukan PPJB yang sebagai perjanjian pendahuluan dengan demikian PPJB berfungsi untuk mempersiapkan atau bahkan memperkuat perjanjian utama/pokok yang akan dilakukan, karena PPJB merupakan awal dari lahirnya perjanjian pokok.

Terhadap berlakunya Permen Agraria dan Tata Ruang Nomor 29 Tahun 2016 ini memaksa orang asing untuk membuat perjanjian pemilikan rumah tempat tinggal baru ataupun membayar kekurangan yang timbul dari nominal pembelian rumah tempat tinggal yang termuat pada perjanjian awal. Ini tentu menimbulkan kerugian bagi Warga Negara Asing sendiri dalam penerapannya yang telah membayar lunas rumah tempat tinggal yang dibelinya.

Jika dilihat pada Permen Agraria dan Tata Ruang Nomor 29 Tahun 2016, masih terdapatnya kelemahan norma untuk melindungi kepentingan orang asing selama melakukan usaha serta kegiatannya di Indonesia. Hal ini dikhawatirkan dapat mengurangi minat Warga Negara Asing itu berinvestasi di Indonesia. Apabila sudah adanya peraturan yang cukup untuk mengakomodir segala kepentingan Warga Negara Asing selama melakukan usaha maka hal tersebut berdampak positif terhadap pertumbuhan perekonomian di Indonesia.

\subsection{Pentingnya Pembentukan Peraturan Perundang-undangan baru dalam rangka Memberikan Perlindungan Hukum bagi WNA yang dirugikan dalam pelaksanaan PPJB atas Pemilikan Rumah Tempat Tinggal dengan WNI}

Hukum berfungsi sebagai sarana untuk mewujudkan ketertiban dan ketenteraman dalam masyarakat, sehingga perlu dijaga hubungan antara anggota masyarakat yang satu dengan anggota masyarakat yang lainnya. Hukum melindungi kepentingan setiap orang dalam bentuk norma atau kaidah. Hukum memiliki sifat yang umum karena hukum berlaku bagi setiap orang dan bersifat normatif karena mengatur boleh tidaknya suatu perbuatan dilakukan, selain itu hukum juga mengatur bagaimana cara pelaksanaan kepatuhan terhadap norma tersebut. Adanya perlindungan hukum menyebabkan anggota masyarakat merasa aman dalam melaksanakan kepentingannya. Berdasarkan hal tersebut, perlindungan hukum dianggap sebagai pemberi jaminan atau kepastian, dalam hal ini setiap orang akan mendapatkan hak dan kewajibannya, sehingga semua pihak merasa aman. 
Pada segi Normatif, konsep penguasaan memiliki sifat sementara yang kemudian masih memerlukan kembali suatu kepastian hukum terkait hubungan antara pihak yang menguasai dengan objek yang dikuasai. ${ }^{10}$ Maka dari itu, penguasaan tanah tidak boleh diabaikan oleh hukum. Mengenai sah atau tidaknya suatu penguasaan tanah oleh WNA diperlukan peraturan yang bersifat melindungi segala perbuatan hukum penguasaan tanah tersebut.

Adanya suatu jaminan atau kepastian hukum tentu memberikan rasa aman bagi WNA selama berkedudukan di Indonesia. WNA juga memiliki hak untuk mendapatkan perlindungan hukum karena hukum merupakan sarana maupun jalan guna mengatur hak dan kewajiban subjek hukum. Perlunya suatu perlindungan hukum guna membatasi kegiatan-kegiatan Warga Negara Asing selama berkedudukan di Indonesia tentunya akan meningkatkan investasi asing di Indonesia yang dapat berdampak positif bagi Indonesia. Melalui investasi, sebagai salah satu cara untuk menciptakan pertumbuhan ekonomi dalam rangka menciptakan lapangan kerja, meningkatkan pendapatan, serta menanggulangi kemiskinan.11

PPJB itu sendiri adalah merupakan penemuan hukum oleh Notaris yang digunakan sebagai penyelesaian terhadap sulitnya syarat-syarat yang harus dilengkapi oleh para pihak sebelum melaksanakan perbuatan hukum jual beli sebagaimana diatur dalam peraturan-peraturan yang berkaitan dengan hak atas tanah. Hal ini dikarenakan, peraturan perundang-undangan belum mengatur mengenai PPJB khususnya yang berkaitan dengan hak atas tanah.

Pada pengaturan Permen Agraria dan Tata Ruang Nomor 29 Tahun 2016, belum adanya suatu norma guna memberikan rasa aman bagi Warga Negara Asing kaitannya dengan adanya transisi ketentuan norma antara Permen Agraria dan Tata Ruang Nomor 13 Tahun 2016 dan Permen Agraria dan Tata Ruang Nomor 29 Tahun 2016. Kaitannya mengenai perbedaan nominal harga pembelian rumah tempat tinggal yang tentu menyulitkan Warga Negara Asing dalam hal pelaksanaan Perjanjian Pengikatan Jual Beli dengan Warga Negara Indonesia, bahwa dalam hal ini mengharuskan Warga Negara Asing membayar kekurangan dari nominal pembelian unit rumah tinggal tersebut yang telah dibayar lunas, maka ini tentu merugikan Warga Negara Asing. Berdasarkan hal tersebut, maka perlu dibentuknya peraturan perundang-undangan yang mampu memberikan perlindungan hukum bagi Warga Negara Asing selama melakukan aktifitasnya di Indonesia. Terhadap PPJB lunas yang telah dibayarkan oleh Warga Negara Asing berkaitan dengan pajak yang timbul karena jual beli tersebut. Pada Permen Agraria dan Tata Ruang Nomor 29 Tahun 2016 dapat dikatakan belum cukup mengakomodir segala kepentingan Warga Negara Asing dalam hal ini melaksanakan perjanjian pengikatan jual beli atas pemilikan rumah tempat tinggal di Indonesia.

10 Saputri, A. D. (2015). Perjanjian Nominee dalam Kepemilikan Tanah Bagi Warga Negara Asing yang Berkedudukan di Indonesia (Studi Putusan Pengadilan Tinggi Nomor: 12/pdt/2014/pt. dps). Repertorium, 2(2). H. 97.

11 Damayanti, N. L. E., \& Kartika, I. N. (2016). Pengaruh Kunjungan Wisatawan Asing dan Investasi terhadap Penyerapan Tenaga Kerja Serta Pertumbuhan Ekonomi. E-Jurnal Ekonomi Pembangunan Universitas Udayana, 5(7). h. 7. 
Pada Pasal 96 ayat (1) Undang-Undang Nomor 12 Tahun 2011 tentang Pembentukan Peraturan Perundang-undangan (selanjutnya disebut dengan UUPPP) mengatur bahwasanya memberikan hak secara lisan maupun secara tertulis pada masyarakat untuk turut serta dalam pembentukan peraturan perundang-undangan. Masyarakat dapat menyalurkan aspirasi secara langsung maupun tidak langsung melalui lembaga perwakilan rakyat. ${ }^{12}$ Partisipasi tersebut dilakukan atas dasar kebebasan bersosialisasi, bicara dan ikut serta secara konstruktif. ${ }^{13}$ Kaitannya terhadap pembentukan peraturan perundang-undangan, dimana Negara hukum harus menjunjung supremasi hukum. Hukum tersebut diletakkan sebagai pedoman tertinggi dalam penyelenggaraan Negara serta pemerintahan, hal ini sesuai dengan teori kedaulatan hukum yang menempatkan hukum sebagai sumber kedaulatan. ${ }^{14}$ Kedaulatan hukum itu sendiri merupakan kekuasaan tertinggi serta absolut tidak ada instansi lain yang dapat menyamakannya.

Pada konsep kedaulatan ini terkandung konsep kewenangan, kekuasaan serta kemampuan yang dipunyai seseorang maupun badan hukum dalam suatu tindakan hukum, yang memiliki dampak kekuatan, paksaan, dominasi serta pengawasan atas orang lain. ${ }^{15 K o n s e p ~ i n i ~ m e n g a s u m s i k a n ~ d i ~ s e t i a p ~ m a s y a r a k a t ~ t e r d a p a t ~ h u k u m ~ y a n g ~}$ mengatur dan ada yang disebut juga sebagai pejabat yang berdaulat. Setiap orang yang memiliki jabatan serta dalam hukum diberikan berlaku dengan nama Negara, harus diikuti oleh masing-masing subjek hukum yang terkait selama pejabat tersebut melaksanakan peraturan perundang-undangan seperti seharusnya, kemudian dapat dijadikan contoh atas sikapnya.

Pemerintah sebagai pejabat yang berdaulat tidak diperkenankan menentukan segala sesuatunya terkait aturan dalam bernegara oleh kewajiban-kewajiban yang tak dapat dipenuhi oleh meraka sendiri, hal ini terkait kebebasan, persamaan maupun mengenai kepemilikan. Ciri-ciri dari Negara yang sejahtera yaitu adanya turut serta pemerintah dalam lingkup kehidupan masyarakat serta dalam melaksanakan fungsi pemerintahan, pemerintah selalu melakukan intervensi terhadap bermacam-macam aspek kehidupan untuk mewujudkan masyarakat yang sejahtera. Pejabat-pejabat yang berdaulat itu yakni, lembaga legislatif, eksekutif dan yudisial yang dalam hal ini menjalankan tugasnya harus mengayomi masyarakat. Lembaga legislatif merupakan lembaga yang memiliki tugas dan tanggung jawab untuk membuat Undang-Undang yang terdiri atas Dewan Perwakilan Rakyat (DPR), DPD, MPR. Kemudian terdapat lembaga eksekutif yang memiliki tugas dan tanggung jawab menerapkan atau melaksanakan Undang-Undang, yang terdiri atas Presiden dan Wakil Presiden beserta Menteri-Menteri. Adapun lembaga Yudisial yang memiliki tugas dan tanggung jawab untuk mempertahankan pelaksanaan dari pada Undang-Undang, yang terdiri atas Mahkamah Agung (MA), Mahkamah Konstitusi (MK), dan Komisi Yudisial. Negara

12 Jati, R. (2012). Partisipasi Masyarakat Dalam Proses Pembentukan Undang-undang yang Responsif. Jurnal Rechts Vinding: Media Pembinaan Hukum Nasional, 1(3), 329-342. h. 333.

${ }^{13}$ Griadhi, N. M. A. Y., \& Utari, A. A. S. (2008). Partisipasi Masyarakat dalam Pembentukan Peraturan Daerah. dalam Jurnal Kertha Patrika, 33(1). h. 1

14 Putra, I. K. C. RELEVANSI KONSEP NEGARA HUKUM PANCASILA DENGAN WELFARE STATE DALAM IMPLEMENTASINYA DENGAN PELAYANAN PUBLIK DI INDONESIA. Jurnal Magister Hukum Udayana (Udayana Master Law Journal), 6(1), 1-12. h.2.

15 Fuady, M. (2013). Teori-Teori Besar (Grand Theory) dalam Hukum. Jakarta: Kencana Prenada Media Group. h. 91. 
bertanggung jawab untuk merumuskan segala peraturan perundang-undangan yang dapat memberikan perlindungan kepada semua pihak dalam melaksanakan suatu PPJB atas kepemilikan hunian oleh WNA. Sehingga para pihak dapat terlindungi hakhaknya. Negara memiliki kekuasaan untuk memberikan perlindungan hak kepada para pihak dalam melakukan perjanjian jual beli atas pemilikan hunian oleh orang asing.

Berdasarkan Teori Kedaulatan, hal ini merupakan tanggung jawab dari Negara dalam merumuskan peraturan perundang-undangan melalui organ-organ Negara yang mampu memberikan perlindungan hukum terhadap para pihak dalam melaksanakan perjanjian pengikatan jual beli atas pemilikan hunian oleh orang asing. Sehingga para pihak dapat terlindungi haknya serta Warga Negara Asing memiliki rasa aman dan nyaman dalam melaksanakan kegiatannya selama berada di Indonesia. Negara mempunyai kekuasaan untuk mewujudkan perlindungan hak dari para pihak dalam melakukan perjanjian jual beli terhadap kepemilikan hunian oleh WNA.

Orang asing yang berkedudukan di Indonesia yang memberikan manfaat, seperti melakukan usaha, bekerja, atau berinvestasi di Indonesia berdasarkan peraturan perundang-undangan yang berlaku sudah sepatutnya mendapatkan perlindungan hukum yang seharusnya demi kelangsungan perkembangan perekonomian serta pembangunan nasional. Maka dari itu, sebagai wujud dukungan terhadap segala kegiatan Warga Negara Asing selama berkedudukan di Indonesia dalam membantu pembangunan nasional, pemerintah sebagai penyalur aspirasi rakyat wajib memberikan perlindungan hukum kepada Warga Negara Asing terhadap adanya transisi peraturan perundang-undangan hal ini dilakukan guna berlangsungnya investasi berkelanjutan oleh Warga Negara Asing.

\section{Kesimpulan}

Pengaturan tentang pemilikan rumah tempat tinggal yang dapat dimiliki Warga Negara Asing selama berkedudukan di Indonesia belum cukup memberikan perlindungan hukum bagi Warga Negara Asing, dalam hal kerugian yang diderita, yang mengharuskan Warga Negara Asing tersebut membayar kekurangan dari nominal pembelian rumah tempat tinggal akibat adanya transisi peraturan perundang-undangan. Pentingnya pembentukan peraturan perundang-undangan baru mengenai pemilikan rumah tempat tinggal oleh Warga Negara Indonesia selama berkedudukan di Indonesia sebagai upaya untuk mewujudkan perlindungan hukum bagi Warga Negara Asing yang telah berkontribusi dalam pembangunan perekonomian nasional.

Pemerintah Indonesia hendaknya untuk segera membuat atau merubah ketentuan norma atau peraturan perundang-undangan mengenai pemilikan rumah tempat tinggal oleh Warga Negara Asing. Hal ini dilakukan agar tidak mengurangi rasa percaya Warga Negara Asing dalam melakukan kegiatannya untuk berinvestasi di Indonesia yang tentunya akan berdampak pada perekonomian nasional. 


\section{Daftar Pustaka / Daftar Referensi}

\section{$\underline{\text { Buku }}$}

Diantha, I. M. P. (2017). Metodologi Penelitian Hukum Normatif. Denpasar: Prenada Media Group

Fuady, M. (2013). Teori-Teori Besar (Grand Theory) dalam Hukum. Jakarta: Kencana Prenada Media Group

Marzuki, P. M. (2011). Penelitian Hukum. Jakarta: Kencana Prenida Media

Muljadi, K., \& Widjaja G. (2010). Perikatan yang Lahir dari Perjanjian. Jakarta: Rajawali Pers

\section{Jurnal}

Amalia, R., \& Darmawan, N. K. (2013). Perkawinan Campuran dalam Kaitannya dengan Undang-undang no. 6 Tahun 2011 Tentang Keimigrasian. Jurnal Fakultas Hukum Universitas Udayana

Damayanti, N. L. E., \& Kartika, I. N. (2016). Pengaruh Kunjungan Wisatawan Asing dan Investasi terhadap Penyerapan Tenaga Kerja Serta Pertumbuhan Ekonomi. EJurnal Ekonomi Pembangunan Universitas Udayana, 5(7).

Griadhi, N. M. A. Y., \& Utari, A. A. S. (2008). Partisipasi Masyarakat dalam Pembentukan Peraturan Daerah. dalam Jurnal Kertha Patrika, 33(1)

Handayani, E. (2009). Penghindaran Pajak Melalui Perjanjian Pengikatan Jual Beli Dengan Kuasa Jual yang Dibuat di Hadapan Notaris di Jakarta Utara. NOTARIUS, 1(1), 37-52

Jati, R. (2012). Partisipasi Masyarakat Dalam Proses Pembentukan Undang-undang yang Responsif. Jurnal Rechts Vinding: Media Pembinaan Hukum Nasional, 1(3), 329-342

Jaya, I. G. P., Utama, I. M. A., \& Westra, I. K. (2018). KEKUATAN HUKUM SERTIFIKAT HAK TANGGUNGAN DALAM HAL MUSNAHNYA OBYEK HAK TANGGUNGAN KARENA BENCANA ALAM. Acta Comitas, 277-285

ORANG, P. R. T. T. O. (2017). JURNAL PRASADA. Jurnal Prasada, 4(2), 24-36.

Putra, I. K. C. RELEVANSI KONSEP NEGARA HUKUM PANCASILA DENGAN WELFARE STATE DALAM IMPLEMENTASINYA DENGAN PELAYANAN PUBLIK DI INDONESIA. Jurnal Magister Hukum Udayana (Udayana Master Law Journal), 6(1), 112

Rosandi, P., \& Henni, B. (2016). Akibat Hukum Jual Beli Hak Atas Tanah Yang Belum Didaftarkan. Jurnal IUS: Kajian Hukum dan Keadilan, 4(3) 
Saputri, A. D. (2015). Perjanjian Nominee dalam Kepemilikan Tanah Bagi Warga Negara Asing yang Berkedudukan di Indonesia (Studi Putusan Pengadilan Tinggi Nomor: 12/pdt/2014/pt. dps). Repertorium, 2(2)

\section{Internet}

Jurnal Hukum. http://www.jurnalhukum.com/syarat-syarat-sahnya-perjanjian/,akses,3, diakses pada tanggal 1 September 2018 